九州大学学術情報リポジトリ

Kyushu University Institutional Repository

\title{
SYSTEMATIC POSITION OF HYPOJAMIDES CATOCHLORIS (BOISDUVAL) (LEPIDOPTERA, LYCAENIDAE)
}

Hirowatari, Toshiya

https://doi.org/10.5109/2541

出版情報 : ESAKIA. Special Issue 1, pp.173-176, 1990-04-20. Entomological Laboratory, Faculty of Agriculture, Kyushu University バージョン :

権利関係 : 


\title{
SYSTEMATIC POSITION OF HYPOJAMIDES CATOCHLORIS (BOISDUVAL) (LEPIDOPTERA, LYCAENIDAE)
}

\author{
TOSHIYA H IROWATARI \\ Entomological Laboratory, College of Agriculture, University of Osaka Prefecture, \\ Sakai, Osaka, 591 Japan
}

\begin{abstract}
Based mainly on the character of female genitalia, Hypojamides is synonymized with Nacaduba resulting in the new combination Nacaduba catochloris (Boisduval).
\end{abstract}

\section{Introduction}

Hypojamides catochloris (Boisduval) is one of the most mysterious lycaenids, which is known to occur on Tahiti Island. Since its description in 1832, the species had never been recorded until Collenette captured a further specimen in 1925, which has been deposited in the British Museum (Natural History). Originally the species was described under the genus Lycaena. Butler (1874) suggested that the species might prove to be Danis. Subsequently Druce (1892) considered it to be Nacaduba without any morphological basis. In 1928, Riley erected the genus Hypojamides for catochloris based on the single female captured by Collenette. He considered that the genus is most closely related to Thysonotis (junior objective synonym of Danis) judging from the general appearance. On the other hand, Eliot (1973) provisionally placed Hypojamides in the Nacaduba section in his higher classification of Lycaenidae.

By courtesy of the staff of the British Museum, I dissected the specimen and recognized that catochloris should belong to the genus Nacaduba Moore, [1881].

Nacaduba ca tochloris (Boisduval) comb. nov.

(Fig. 1,2)

Lycaena (?) catochloris Boisduval, 1832. Voy. "Astrolabe," Faun. ent. 1(Lep.) : 78

Lycaena (3) catochloris : Butler, 1874. Proc. zool. Soc. Lond., $1874: 286$.

Nacaduba (?) catochloris: Druce, 1892. Proc. zool. Soc. Lond., 1892: 440.

Hypojamides catochloris : Riley, 1928. In Poulton \& Riley. Trans. ent. Soc. Lond., 1928 : 466-467.

Female genitalia (Fig. 2). Apophysis anterioris slender, about $1 / 5$ as long as 8 th tergum. Intersternal pouch relatively shallow, well sclerotized anteriorly. Corpus bursae globular and relatively small ; signa a pair of inwardly projecting spines, situated on the posterior portion of corpus bursae. Caudal portion of ductus bursae weakly sclerotized, with a weak swelling ventrally. 

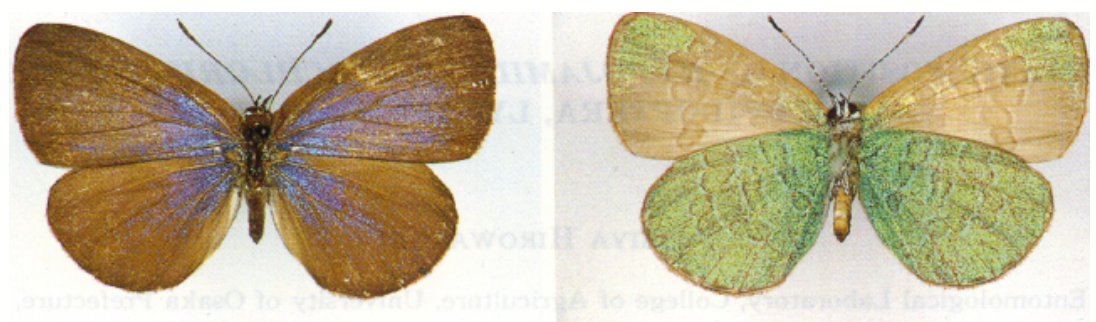

Fig. 1. Nacaduba catochloris (Boisduval) comb. nov. A : Female, upperside. B : Ditto, underside.

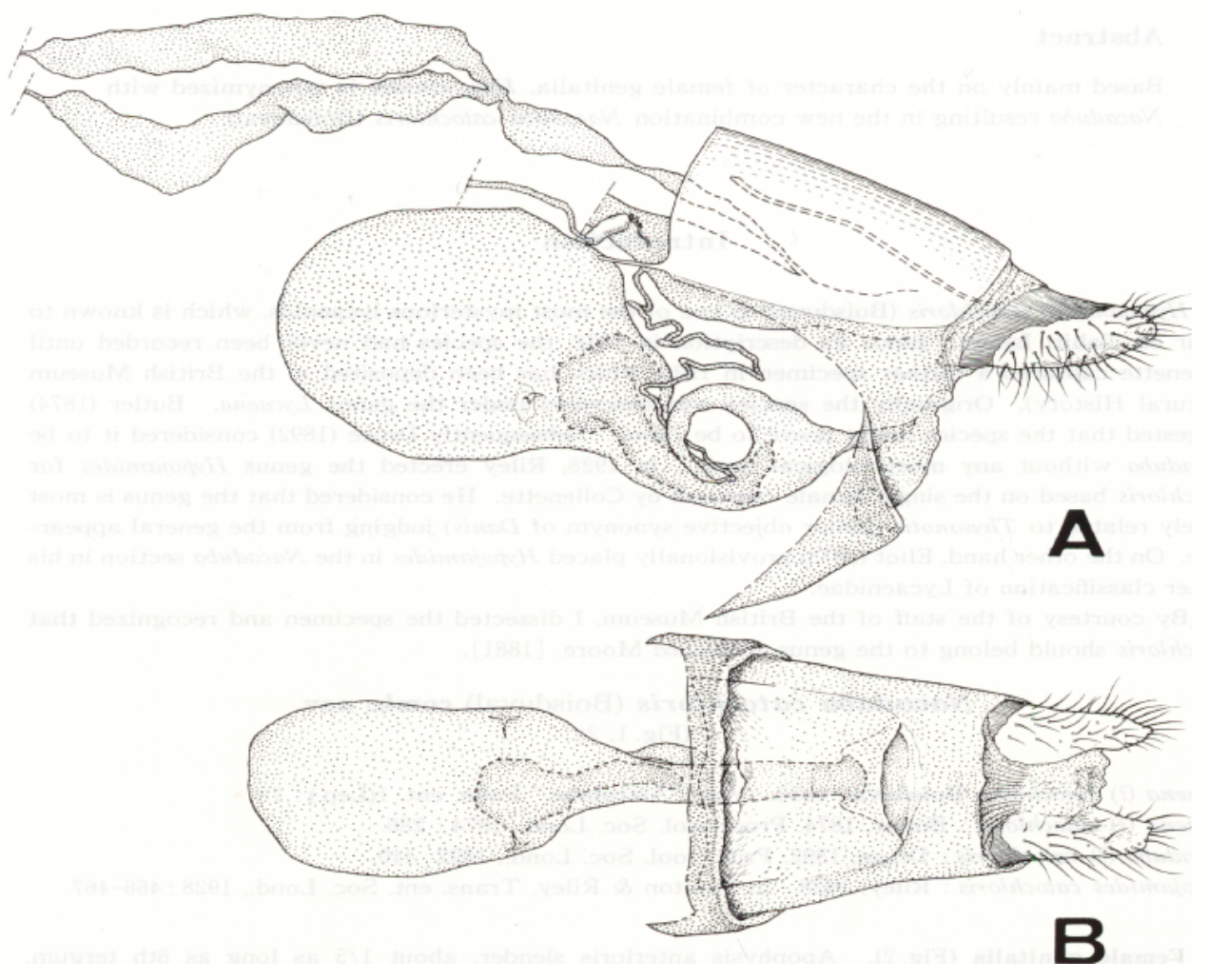

Fig. 2. Female genitalia of Nacaduba catochloris (Boisduval) comb. nov. A : Internal reproductive organs, lateral aspect. B:Ditto, ventral aspect. 
Ductus seminalis gradually swollen toward the point of attachment to ductus bursae. Ostium opened at the middle of 8 th abdominal venter.

Remarks. The above description has been based on the specimen of catochloris which is preserved in the British Museum (Natural History), labelled "Fautaua Valley,/Tahiti,/Near Stream,/ 2,500 ft. 11. 3. 25./St. George Expedn./C. L. Collenette."

In 1989, Hara and Hirowatari \{described Nacaduba tahitiensis based on 28 males and 3 females from Tahiti Island. All the specimens were collected by Mr. Hara on September 18, 1988. As they pointed out, tahitiensis resembles catochloris in having green metallic scales on the underside of hindwing, but is clearly descriminated from the latter by the green scales which are present only in the inner area of submarginal lunulae. Previously Holloway (1983) had recorded a series of 'catochloris', but Hara and Hirowatari overlooked it and regarded the female specimen in the BMNH as a unique one. Recently I was able to examine the series, by courtesy of Dr. Holloway, and confirmed that the series consists of only one female catochloris and seven tahitiensis. The comments of Holloway (1983) on the systematic position of 'catochloris' apparently refer to tahitiensis.

In the female genitalia, the two species are separable as follows : in catochloris the bursa copulatrix is relatively short, about $2 \times$ as long as the 8 th tergum, but in tahitiensis it is about $3 \mathrm{X}$ as long as the 8th tergum ; in catochloris the signa are situated on the posterior portion of corpus bursae, but in tahitiensis they are nearly at the middle of corpus bursae ; in catochloris the caudal sclerotized portion of ductus bursae with a weak welling ventrally, but it is represented by a prominent condyle in tahitiensis.

\section{Discussion}

Concerning the systematic position of 'Lycaena catochloris', Butler (1874) added a short comment in his list of diurnal Lepidoptera of the South Sea Islands, "I suspect that this is a Danis". Though Druce (1892) had never examined the specimen, he considered it might turn out to be a Nacaduba because Danis had not been known to occur among these islands of South Pacific Ocean.

Riley (1928) erected the genus Hypojamides based on a single female of catochloris which had been obtained by Collenette in 1925 . He considered that the genus is most related to Thysonotis judging from the general characters, such as palpi, antennae and wing venation. Riley also pointed out that Hypojamides may be separated from Thysonotis by the position of the origin of vein 2 of forewing which is much nearer to vein 3. However, by these characters, Hypojamides can not be separable from Nacaduba. Moreover in catochloris, the veins 11 and 12 of fore wing are anastomosed briefly at the middle, and then divergent again. This is also characteristic of some genera of the Nacaduba section. In the female genitalia, the corpus bursae of the species is very small bearing a pair of developed signa ; the ductus seminalis is gradually swollen toward the attachment point to ductus bursae. These features apparently congruent with the character of the genus Nacaduba which I (1986) pointed out.

The further discussion of the systematic position of catochloris should await the discovery of the male.

\section{Acknowledgements}

I wish to express my hearty thanks to Professor Emeritus Y. Hirashima of Kyushu University for his hearty encouragement. I am also much indebted to Mr. P. R. Ackery of British Museum (Natural History), Lt. Col. J. N. Eliot, Taunton, U. K. and Dr. J. D. Holloway, C. A. B. International Institute of Entomology, London for critical advice and giving me opportunities to examine valuable 
specimens.

\section{References}

Boisduval, J. B., 1832. Voy. “Astrolabe,” Faun.ent. 1 (Lep.) : 78.

Butler, A. G., 1874. List of the diurnal Lepidoptera of the South-Sea Islands. Proc.zool.Soc.Lond., $1874: 286$

Druce, H. H., 1892. A list of the Lycaenidae of the South Pacific Islands east of the Solomon Group, with descriptions of several new species. Proc.zool.Soc.Lond., 1892 : 440.

Eliot, J. N., 1973. The higher classification of the Lycaenidae (Lepidoptera) : a tentative arrangement. Bull. Br. Mus. nat. Hist. (Ent.) 28 :373-505, 162 figs. 6 pls.

Hara, M., and T. Hirowatari, 1989. A new species of the genus Nacaduba Moore (Lepidoptera, Lycaenidae) from Tahiti Island. Tyô to Ga, 40(3): 133-139.

Hirowatari, T., 1986. Morphology and taxonomic importance of the female genitalia of the genus Nacaduba Moore (Lepidoptera, Lycaenidae). Tyô to Ga, 37(2): 51-60.

Holloway, J. D., 1983. The biogeography of the Macrolepidoptera of South-Eastern Polynesia. Geo Journal $7.6: 517-525$.

Riley, N. D., 1928. In Poulton, E. B. \& N. D. Riley. The Rhopalocera of the "St. George" expedition from French Oceania. Trans. ent.Soc. Lond., $1928: 466-467$. 